\title{
Uraohjaajien osaaminen ja haasteet työelämän murroksessa
}

\begin{abstract}
10
Uraohjaajien on tunnettava työalansa, osattava soveltaa osaamistaan sekä kyettävä joustamaan, ennakoimaan ja hyödyntämään metakognitiivisia taitoja työssään. Psykologisen osaamisen korostuminen

heijastelee asiakkaiden tilanteita ja jatkuvassa muutoksessa olevaa, kiivastahtista työelämää. Olennaista on, miten uraohjaajat pystyvät tukemaan asiakkaiden merkityksellisiä, motivoivia ja kiinnostavia urapolkuja ja samalla vastaamaan yhteiskunnan muuttuviin tarpeisiin.
\end{abstract}

$\mathbf{y}$

TYÖELÄMÄSTÄ ON TULLUt YHÄ intensiivisempää, ja työn sisällölliset vaatimukset ovat kasvaneet (Julkunen 2008; Kubicek \& Tement 2016). Erityisesti teknologian kehitys, globalisaatio ja demografian muutos ovat luoneet työelämään murrosta (Kettunen 2017; Oksanen 2017). Teknologia muokkaa tehtävärakenteita ja työskentelytapoja (Kauhanen 2014) samalla kun monikulttuurisuus on lisääntynyt työelämässä, ja moni muuttaa työn perässä ulkomaille (Coutinho, Dam \& Blustein 2008). Lisäksi elatussuhde heikkenee ja nuoret ikäluokat ovat aiempaa korkeammin koulutettuja (Kauhanen 2014), jolloin työmarkkinoille tulijoiden ja sieltä poistuvien tietotaitoja voi olla vaikea sovittaa yhteen.
Yksilön kannalta työnteon kuormittavuus ja vaatimukset ovat lisääntyneet, sillä työntekijöiden odotetaan osallistuvan erilaisten tiimien ja yhteisöjen toimintaan samalla kun vastuu on lisääntynyt ja työ on yhä ennustamattomampaa (Kubicek \& Tement 2016; Savickas 2013).

Tarve pidentää työuria tarkoittaa sitä, että uransa loppupuolella työntekijän on aktiivisesti etsittävä ja löydettävä joustavia tapoja jatkaa työntekoa. Tarvitaan siis uusia tapoja ajatella, kehittää ja hallita työn roolia yksilöiden elämässä. (Hartung 2010.)

Työelämän muutoksissa uraohjaajien rooli korostuu. Heiltä vaaditaan kykyä tuottaa kulttuurisensitiivisiä palveluita yhä monimuotoisemmalle asiakaskunnalle 


\section{URAOHJAAJIEN ON}

KYETT $\ddot{A} V \ddot{A}$ TUOTTAMAAN

\author{
KULTTUURISENSITIIVISI $\ddot{A}$ \\ PALVELUITA YH $\ddot{A}$ \\ MONIMUOTOISEMMALLE
}

ASIAKASKUNNALLE.

(Coutinho ym. 2008), hallita teknologiaa ja sopeutua sen tuomiin muutoksiin (Harteis 2018) sekä sovittaa työssään dynaamisesti yhteen kognitiivisia, sosiaalisia, emotionaalisia ja eettisiä tekijöitä (Vuorinen \& Kettunen 2017).

Nopeasti muuttuvien urien ristipaineessa painottuu uraohjauksen merkitys. 'Uraohjauksella' tarkoitamme niitä palveluita, joilla autetaan eri elämäntilanteissa ja -vaiheissa olevia asiakkaita kehittämään merkityksellistä elämänkulkua ja tekemään oppimista, työtä ja siirtymiä koskevia päätöksiä (Eurooppalainen elinikäisen ohjauksen toimintapolitiikan verkosto = ELGPN 2014; Lent \& Brown 2013). 'Uraohjauksella' tarkoitamme myös asiakkaan tekijyyden tukemista hänen elämänsä tärkeissä kysymyksissä (Peavy 1999).

Useat kansainväliset ja kansalliset yhdistykset, muun muassa International Association for Educational and Vocational Guidance (IAEVG 2003), Euroopan ammatillisen koulutuksen kehittämiskeskus (CEDEFOP 2009), The National Career Development Assoaciation (NCDA 2009), Canadian Standards and Guidelines for Career Development (S\&Gs 2012) ja Network for Innovation in Career Guidance and Councelling in Europe (NICE 2016), ovat julkaisseet uraohjaajien osaamisviitekehyksiä. Vaikka osaamisviitekehykset eivät itsessään ole tutkimustuloksia, käytämme niitä taustoittamaan tutkimustamme, sillä ne ovat kansallisissa ja kansainvälisessä yhteistyössä kehitettyjä sekä laajalti käytettyjä. Osaamisviitekehykset pohjautuvat moninaisiin yhteiskunnallisiin näkemyksiin, alan asiantuntijoiden tietotaitoon ja tutkimustietoon. Työelämän ja ura- ohjaajien työn nopeiden muutosten vuoksi on tärkeää tutkia uraohjaajien omia kokemuksia työstään ja osaamistarpeistaan sekä tarkastella kokemusten yhtenevyyttä normatiivisiin osaamisviitekehyksiin.

Tavoitteemme on tutkia uraohjaajien kokemuksia työstään seuraavien tutkimuskysymysten pohjalta:

1. Millaista osaamista uraohjaajat kokevat tarvitsevansa työssään?

2. Millaisia haasteita uraohjaajat kokevat kohtaavansa työssään?

Haasteita ja osaamista tarkastelemalla voidaan kehittää uraohjausta sekä varmistaa sen laatua ja tehokkuutta (Sultana 2009). Tutkimus tuo esiin uraohjaajien näkökulman siitä, mikä on suomalaisen uraohjauksen kentällä ajankohtaista. Lisäksi se kiinnittyy laajempaan ja yleisluontoiseen uraohjaajien osaamisen tutkimukseen, jonka avulla on mahdollista osallistua kansainväliseen keskusteluun uraohjaajien osaamisesta ja työn haasteista.

\section{URAN JA IDENTITEETTIEN MUUTOS}

Muutokset yhteiskunnassa ja työmarkkinoilla ovat muuttaneet myös työn merkitystä. Työntekijöiden on nykyisin kyettävä neuvottelemaan identiteetistään, kun uria koskevien päätösten määrä on lisääntynyt ja tilanteet ovat yhä epäselvempiä (LaPointe 2014; Vanhalakka-Ruoho 2014). Identiteetti nähdään läpi elämän kehittyvänä mutta suhteellisen pysyvänä sisäisenä kokemuksena itsestä (Erikson 1994). Yksilö voi määritellä onnistuneen uran elämänkuluksi, jossa vuorottelevat opiskelu, työnteko tai sapattivuodet (Vanhalakka-Ruoho 2014; Vehviläinen 2014).

Elämää voidaan tarkastella kokonaisuutena, jossa työ on yksi elämänkentän osa, ja elämänkentän eri osa-alueet ovat vuorovaikutuksessa keskenään (Savickas ym. 2009). Työ siis ajatellaan osaksi kokonaisvaltaista yksilön elämän ja identiteetin kokonaisuutta, minkä myötä alan kirjallisuudessa esitetyt määritelmät ja käsitykset urasta ovat muuttuneet. Nykyisin 'uralla' ei siis tarkoiteta ainoastaan 'työuraa' vaan usein myös laajemmin 'elämänuraa'. (Hartung 2010; Savickas ym. 2009.) Lisäksi työelämän intensiivisyys ja konfliktit vaikuttavat väistämättä 


\section{URIEN KEST ̈̈VYYTTÄ HAASTAA}

ETENKIN TYÖN PSYKOLOGISEN

SOPIMUKSEN MUUTOS.

koko elämänkentän kattavaan hyvinvointiin, minkä vuoksi uria käsiteltäessä ei voida olla huomioimatta myös muita konteksteja, joihin ne ovat sidoksissa (Kubicek \& Tement 2016; Peavy 1999).

Kestävän uran prosessimalli (process model of sustainable careers) ottaa huomioon uravalintojen pitkäaikaiset vaikutukset sekä yksilön ja hänen uransa yhteensopivuuden systeemisen ja dynaamisen luonteen (Vos, de \& Heijden, van der 2015). Urien kestävyyden osatekijöitä ovat fyysinen ja psyykkinen terveys, onnellisuus ja subjektiivisesti koettu tyytyväisyys omaan uraan sekä tuottavuus, jotka näyttäytyvät työhön liittyen työkykynä, sitoutumisena ja suoriutumisena (Vos, de \& Heijden, van der \& Akkermans 2018).

Kestävyys on olennaista urien pidentymisen sekä työn ja muun elämän yhteensovittamisen kannalta. Kestävä ura tähtääkin siihen, että ura on integroitu tyydyttävästi henkilökohtaiseen elämään, ja kokonaisuus sopii yksilön arvomaailmaan, tarjoaa taloudellisen turvallisuudentunteen sekä mahdollistaa joustavuuden ja työn uusintamisen vielä uran loppupuolellakin. (Vos, de \& Heijden, van der 2015.)

Urien kestävyyttä haastaa erityisesti työn psykologisen sopimuksen muutos, jonka myötä työn jatkuvuus on epävarmaa ja määräaikaiset työsuhteet yhä yleisempiä (Vos, de \& Heijden, van der 2015). Kun jokainen keskittyy omaan uraansa eikä kiinnity tiettyyn organisaatioon tai työyhteisöön, kokemus yksinäisyydestä on lisääntynyt. Eriytyneisyyttä lisäävät organisaatioiden nopeat rakennemuutokset ja teknologian mahdollistamat joustavat työajat ja etätyöt (Harteis 2018).

Samalla ammattilaisten odotetaan vastaavan sosiaalisiin odotuksiin, olevan innovatiivisia ja tekevän ammatilliset ja organisaatioiden rajat ylittävää yhteistyötä. Tunteiden ja tunneälyn merkitys on kasvanut, sillä kumpikin linkittyy vahvasti työntekoon, uravalintoihin ja yksilön muuttuviin identiteetteihin. (Vähäsantanen \& Eteläpelto 2015.)

Vaikka työ tukee mielenterveyttä, epävarmuus ja henkinen kuormitus työelämässä ovat lisääntyneet yhtäläisesti niin suomalaisten (Julkunen 2008; Työolotutkimus 2013) kuin kansainvälisten havaintojen mukaan (Vos, de \& Heijden, van der 2015; Lent \& Brown 2013). Työelämän ristiriidoista selvitäkseen työntekijät tarvitsevat toimintakykyä ja yksilöllisiä voimavaroja, kuten sosiaalisen verkoston sekä joustavuutta ja itseluottamusta (Onnismaa 2007; Pietikäinen 2017). Uraohjauksella voidaan vähentää työelämän negatiivisia psykologisia vaikutuksia luomalla merkityksellisiä työkonteksteja, joissa yhdistyvät yksilön toimijuus, kompetenssit ja mahdollisuus kehittää itseä (Coutinho ym. 2008). Optimaalisen tuen avulla työnteko voi johtaa yksilön kokemukseen itsensä toteuttamisesta ja tyytyväisyydestä elämään (Vos, de ym. 2018), mikä voi olla voimaannuttavaa ja kehittää kokonaisvaltaista hyvinvointia (Niles, Yoon, Balm \& Amundson 2010).

Samalla kun yksilön valta ja vastuu omasta työstä lisääntyvät, yksilöllisten ratkaisujen ja uravalmennusten kysyntä kasvaa (Kauhanen 2014). Yhä yksilöllisempi ohjaus auttaa luomaan kestävää uranhallintaa (Peavy 1999; Vehviläinen 2014), minkä vuoksi tarvitaan yhä monipuolisempia tapoja antaa ohjausta ja samalla varmistaa sen laatu muuttuvissa vaatimuksissa.

\section{URAOHJAUS JA URAOHJAAJIEN OSAAMINEN}

Työelämäsuuntautuneesta ohjauksesta voidaan puhua monilla käsitteillä, ja uraohjauksen ammattilaisten nimikkeet vaihtelevat organisaatioittain. Jotkut uraohjauksen ammattilaiset käyttävät 'ohjausta' ja 'neuvontaa' synonyymeinä, toiset erottavat ne. (Douglas 2010; Onnismaa 2007.) Käytämme 'uraohjausta', koska se on käsitteistä sisällöltään laajin ja sitä on käytetty tieteellisessä tutkimuksessa (esim. Sultana 2009; Vuorinen \& Kettunen 2017) ja julkisissa laitoksissa, kuten työ- ja elinkeinotoimistoissa (Työ- ja elinkeinotoimisto 2018).

'Ohjaus' puolestaan on märiteltävissä tavoitteelliseksi yhteistyösuhteeksi, jossa sekä ohjaajalla että asiakkaalla on oma asiantuntijuuden alueensa (Peavy 1999). Pidämmekin uraohjausta toimintana, joka lisää 


\section{URAOHJAUSTA}

\section{AMMATTIALANA LEIMAA}

TOISINAAN SIRPALEISUUS.

asiakkaan itseymmärrystä ja kehittää tämän valmiuksia toimia muuttuvissa työ- ja oppimisympäristöissä. Lisäksi uraohjauksen ajatellaan tukevan urien kestävyyttä sovittamalla yhteen yksilöiden urakokemuksia, sosiaalisia tiloja ja toimijuutta merkityksellisellä tavalla (Vos, de \& Heijden, van der 2015). Uraohjausta voidaankin pitää poliittisena prosessina yksilöllisten ja yhteiskunnallisten tarpeiden välillä (Vehviläinen 2014). Myös voimaannuttaminen on tärkeä osa uraohjausprosessia, sillä toiveikkuus ja omien vahvuuksien tunnistaminen lisäävät yksilön palautumiskykyä ja kokonaisvaltaista hyvinvointia (Niles ym. 2010).

Uraohjausta ammattialana leimaa kuitenkin toisinaan sirpaleisuus, sillä kentällä toimivien koulutus- ja osaamistaustat ovat kirjavia. Asiakkaat eivät aina tiedä, millaisesta ohjauksesta on kyse (Douglas 2010). Euroopan unionissa uraohjaajien pätevyysvaatimukset vaihtelevat laajasti, vaikka uraohjaajien osaamisen tunnistamista pidetään keskeisenä tekijänä työllisyystavoitteiden saavuttamisessa (Vuorinen \& Kettunen 2017). Tästä syystä tutkimuksemme keskittyy uraohjaajien osaamiseen. Osaamisen ajatellaan sisältävän tietojen ja taitojen eli kompetenssien lisäksi kokemuksen, sosiaaliset verkostot sekä arvot (Lindsay \& Stuart 1997). Osaamisen määritelmä ottaa näin huomioon tiedon yksilölliseen tulkitsemiseen ja ymmärtämiseen sidoksissa olevat seikat ja on siksi kokonaisvaltaisempi käsite kuin kompetenssi (Mulder 2007; Sultana 2009).

Uraohjaajien osaamisviitekehykset sisältävät yhteisiä ydinelementtejä uraohjaajien koulutukseen ja laatuvaatimuksiin sekä lisäävät toimijoiden välistä yhteisymmärrystä, yhteistyötä ja liikkuvuusmahdollisuuksia (Vuorinen \& Kettunen 2017). Viitekehykset eivät itsessään ole kuvauksia todellisuudessa toteutuvasta ohjaustyöstä ja käytänteistä vaan pikemminkin laatustandardeja, joita kohti koulutusten ja uraohjauksen ammattilaisten toivotaan pyrkivän.
Aiemmin kehitetyissä osaamisviitekehyksissä, kuten NCDA, CEDEFOP, S\&Gs, IAEVG ja NICE, voidaan nähdä yhdeksän toistuvaa osaamisaluetta:

1. eettisyys: tiedostaa työn eettiset näkökulmat, selventää ne asiakkaalle ja toimii niiden mukai sesti

2. ohjaustaidot: käyttää ohjausta tehokkaasti ja tarkoituksenmukaisesti, kykenee huomioimaan asiakkaiden moninaisuuden ja vastaamaan heidän tarpeisiinsa

3. kulttuurisensitiivisyys: kunnioittaa asiakkaan kulttuuria, tiedostaa omat kulttuuriset uskomuksensa ja oletuksensa

4. itsetuntemus: tiedostaa omat kykynsä, arvonsa ja rajoituksensa

5.uraohjauksen tuntemus ja soveltaminen: arvioi ja soveltaa moninaisia ohjausmenetelmiä

6. ammatillinen kehittyminen: arvioi poliittisia, sosiaalisia ja taloudellisia tekijöitä sekä kehittää aktiivisesti osaamistaan

7. verkostoituminen: kehittää ja ylläpitää verkostoja kollegoihin ja sidosryhmiin

8. teoriatieto: ymmärtää ja soveltaa moninaisia teorioita käytäntöön

9. teknologiaosaaminen: tuntee verkko-ohjausta ja pystyy käyttämään teknologiaa työssään.

Uraohjaajien tarvitsemaa osaamista voi pitää kokonaisvaltaisena siten, että se sisältää asiakastyön lisäksi sosiaaliset verkostot ja ohjaajan oman toiminnan. Osaamistarpeet voivat kuitenkin vaihdella organisaation toimintaympäristön mukaan (Lindsay \& Stuart 1997).

\section{AINEISTO JA ANALYYSI}

Tutkimme uraohjaajien kokemuksia omasta työstään, jolloin aineistonkeruumenetelmäksi valikoitui avoin haastattelu (Patton 2002). Tutkimukseen haastateltiin yhdeksää uraohjaajaa, jotka työskentelivät sekä yksilö-, ryhmä- että etäohjauksessa.

Haastateltavat tavoitettiin osittain Uraohjaajat ja -valmentajat ry:n sähköpostilistalta, joka kattaa noin 150 uraohjauksen ammattilaista ympäri Suomea. Listalta saatiin neljä haastateltavaa, joten heidän 
joukkoaan täydennettiin lumipallo-otannalla, eli haastateltava ehdotti toista asiantuntijaa, joka voisi olla kiinnostunut osallistumaan tutkimukseen (Patton 2002). Näin tavoitettiin vielä viisi haastateltavaa. Haastattelut kestivät 50 minuutista yli kahteen tuntiin, keskimäärin 75 minuuttia. Haastattelumateriaalia kertyi 11 tuntia.

Haastateltavat olivat toimineet ohjauksen parissa keskimäärin yhdeksän vuotta. He työskentelivät sekä syrjäseuduilla että isoissa kaupungeissa, ja jotkut olivat aiemmin toimineet valtakunnallisesti etäohjauksessa. Neljä työskenteli haastatteluhetkellä työ- ja elinkeinotoimistoissa, yksi koulutussektorilla ja neljä yksityisissä yrityksissä. Neljä oli peruskoulutukseltaan psykologeja, ja viidellä oli opetus- tai sosiaali- ja terveysalan peruskoulutus tai molemmat. Taustatekijöiden valossa haastateltavien joukkoa voi pitää hyvänä, harkittuna ja tarkoituksenmukaisena otoksena tutkimuksen tavoitteiden näkökulmasta.

Haastattelut suoritettiin avoimina asiantuntijahaastatteluina (Meuser \& Nagel 2009). 'Asiantuntijalla' tarkoitamme henkilöä, joka on työskennellyt uraohjauksen kentällä ja jolla on kokemuksen kerryttämää erityistä tietoa tutkimusaiheesta. Avoimen haastattelun periaatteiden mukaisesti valmiita kysymyksiä tai teemoja ei tarjottu, vaan uraohjaajat saivat vapaasti kertoa omista osaamistarpeistaan ja haasteistaan omien kokemustensa ja käsitystensä mukaisesti. Haastattelut toteutettiin kuitenkin vuorovaikutteisesti: niiden aikana kysyttiin tarkentavia ja aihetta koskevia lisäkysymyksiä. Lopuksi kaikille haastateltaville tarjottiin mahdollisuus tarkentaa haastattelussa käsiteltyjä asioita jälkikäteen sähköpostitse. Näin kertyi lisäaineistoa kahdelta haastateltavalta yhteensä viisi sivua.

Analyysin tarkoitus oli kuulla haastateltavien ääntä ja tuoda esiin heidän kokemusperspektiiviään. Heille annettiin anonymiteetin säilyttämiseksi satunnaisessa järjestyksessä koodinimet H1-H9. Sähköpostitse saadut tekstiaineistot nimettiin koodinimillä T1 ja T2.

Aineisto analysoitiin molempien tutkimuskysymysten osalta luokittelevalla sisällönanalyysilla käyttämällä induktiivista lähestymistapaa, joka sisältää aineistolähtöisen koodauksen, luokittelun ja käsitteellistämisen (Elo \& Kyngäs 2008; Vaismorandi, Turunen \& Bondas 2013). Koska yksittäisten sanojen käyttäminen analyysiyksikkönä voi johtaa analyysin hajanaisuuteen (Elo \& Kyngäs 2008; Vaismorandi ym. 2013), yksiköksi valittiin virke tai ajatuskokonaisuus. Aineiston koodauksen jälkeen analyysiyksiköt käytiin tarkasti läpi, ja samaa tarkoittavat tai samaan teemaan kuuluvat virkkeet ja ajatuskokonaisuudet yhdistettiin alaluokiksi.

Seuraavaksi aineistoa pyrittiin käsitteellistämään yhdistämällä alaluokkia yläluokiksi, joita yhdisteltiin edelleen pääluokiksi. Luokittelu eteni pääosin aineistolähtöisesti, mutta yläluokkien muodostamisessa käytettiin aiempia osaamisviitekehyksiä avaamaan uusia ajattelu- ja jäsennystapoja. Resilienssi ja metakognitiiviset kyvyt - pääluokan käsitteellistämisessä hyödynnettiin kognitiivisen käyttäytymisterapian ja positiivisen psykologian kirjallisuutta (Pietikäinen 2017; Seligman \& Csikszentmihalyi 2000), koska tämän tieteenalan tarjoamat käsitteet kuvasivat hyvin syntynyttä pääluokkaa ja sen sisältöjä. Aineistosta laskettiin, kuinka moni haastateltava puhui kustakin osaamisalueesta tai haasteesta $(\mathrm{N})$.

\section{URAOHJAAJIEN KOKEMAT OSAAMISTARPEET}

Uraohjaajien kokemat osaamistarpeet voidaan tiivistää kahteen laajaan pääluokkaan: 1) uraohjauksen tuntemus ja soveltaminen sekä 2) uraohjaajien resilienssi ja metakognitiiviset kyvyt (taulukko 1).

\section{Uraohjauksen tuntemus ja soveltaminen}

Asiakkaan vahvistamiseen kuuluvana erityisenä osaamistarpeenaan kaikki uraohjaajat kokivat psykologisen osaamisen. Se näyttäytyi siten, että mielenterveysongelmia, traumoja ja kuntoutusta koskevien teemojen käsittely oli lisääntynyt ja erilaisten traumojen ja ahdistuksen käsittely arkistunut. Psykologisen osaamisen tarve näyttäytyi niin ikään uraohjaajien täydennyskoulutuksissa, jotka koskivat muun muassa terapeuttisia menetelmiä, oppimisvaikeuksia ja työkyvyn arviointia. Uraohjaajat korostivat, ettei varsinaista terapiaa kuitenkaan anneta, vaan uraohjaaja ja terapeutti on erotettava toisistaan. 


\begin{tabular}{|c|c|c|}
\hline Pääluokka & Yläluokka & Alaluokka \\
\hline \multirow[t]{6}{*}{$\begin{array}{l}\text { Uraohjauksen } \\
\text { tuntemus ja } \\
\text { soveltaminen }\end{array}$} & Asiakkaan vahvistaminen $(\mathrm{N}=9)$ & $\begin{array}{l}\text { a. Psykologinen osaaminen } \\
\text { b. Voimaannuttaminen } \\
\text { c. Osaamisen tunnistaminen }\end{array}$ \\
\hline & Vuorovaikutusosaaminen $(\mathrm{N}=9$ ) & $\begin{array}{l}\text { a. Asiakkaiden kohtaaminen } \\
\text { b. Tunneäly ja tunnetaidot }\end{array}$ \\
\hline & Teknologinen osaaminen $(\mathrm{N}=9)$ & $\begin{array}{l}\text { a. Etäohjaus } \\
\text { b. Sosiaalinen media } \\
\text { c. Ymmärrys digitalisaation vaikutuksista työelämään }\end{array}$ \\
\hline & Monipuoliset ohjaustaidot $(\mathrm{N}=8)$ & $\begin{array}{l}\text { a. Soveltamiskyky } \\
\text { b. Teoriatieto } \\
\text { c. Lakiosaaminen }\end{array}$ \\
\hline & Ammatillinen kehittyminen $(N=8)$ & $\begin{array}{l}\text { a. Osaamispohjan jatkuva päivittäminen } \\
\text { b. Ennakointikyky }\end{array}$ \\
\hline & Kansainvälisyysosaaminen $(\mathrm{N}=7)$ & $\begin{array}{l}\text { a. Kansainvälisten työmarkkinoiden ymmärrys } \\
\text { b. Kulttuurisensitiivisyys }\end{array}$ \\
\hline \multirow{4}{*}{$\begin{array}{l}\text { Uraohjaajien } \\
\text { resilienssi ja } \\
\text { metakognitiiviset } \\
\text { kyvyt }\end{array}$} & Verkostostoissa toimiminen $(\mathrm{N}=7)$ & $\begin{array}{l}\text { a. Moniammatillinen yhteistyö } \\
\text { b. Työyhteisötaidot ja kollegiaalisuus } \\
\text { c. Itsensä markkinoiminen }\end{array}$ \\
\hline & Tietojenkäsittelyn taidot $(\mathrm{N}=6)$ & $\begin{array}{l}\text { a. Tiedon jäsentäminen } \\
\text { b. Suurten tietomäärien hallinta } \\
\text { c. Tiedonhaun taidot }\end{array}$ \\
\hline & Työhyvinvointitaidot $(\mathrm{N}=6)$ & $\begin{array}{l}\text { a. Armollisuus itseä kohtaan } \\
\text { b. Epävarmuuden sieto }\end{array}$ \\
\hline & Eettinen osaaminen $(\mathrm{N}=6)$ & $\begin{array}{l}\text { a. Ammattietiikka } \\
\text { b. Itsetuntemus }\end{array}$ \\
\hline
\end{tabular}

Taulukko 1. Luokittelu uraohjaajien kokemista osaamisalueista.

Haastateltavat kokivat, että monillakaan asiakkailla ei ole uskallusta tai rohkeutta tehdä päätöksiä ja viedä elämäänsä eteenpäin, joten heidän on kannustettava ja motivoitava asiakkaitaan aiempaa enemmän. Voimaannuttamisen ulottuvuus ilmeni kasvavana tarpeena tukea asiakkaiden itsetuntoa, vähentää heidän epävarmuuttaan ja lisätä heidän toiveikkuuttaan:

"Kyllä tää [työelämä] vaatii asiakkailtakin sellasta psyykkistä kestävyyttä ja joustavuutta, enemmän metataitoja, ja näihin meidän pitää taas pystyä enempi vastaamaan, sen asiakkaan vahvistamiseen ja toiveikkuuden lisäämiseen ja joustavuuden lisäämiseen." (H4)

Haastateltavat pitivät niin ikään tärkeänä osaamisen tunnistamista ja tukemista, sillä harva asiakas osaa itse sanoittaa tai tunnistaa osaamistaan. Osaamisen tunnistaminen koettiin tärkeäksi sekä työelämään sijoittumisen että heikkenevän huoltosuhteen vuoksi.

Vuorovaikutusosaamisen ytimeksi haastatellut kokivat asiakkaiden kohtaamisen, sillä muutosta tapahtuu vasta, kun asiakas on kokenut tulleensa nähdyksi ja kuulluksi sellaisena kuin on. Kuuntelutaitoisen ja empaattisen uraohjaajan onkin helppo rakentaa luottamusta ja siten edistää ohjauksen eettisyyttä. Merkityksellisinä asiakkaiden kohtaamisen osa-alueina haastateltavat pitivät lisäksi yhteistyötaitoja, joustavuutta ja kokonaisvaltaisuutta.

Myös tunneäly ja tunnetaidot olivat haastateltavien mukaan tärkeitä vuorovaikutusosaamisen muotoja, sillä asiakkaat imevät ympäriltään itseensä oletuksia ja asenteita, jotka vaikuttavat heidän tunteisiinsa ja käyttäytymiseensä. Vaikeiden asioiden käsittely vaatii uraohjaajilta tunneälyä ja herkkyyttä 
TEKNOLOgisia taitoja Ja

TYÖELÄMÄN DIGITALISAATION

\author{
YMMÄRRYSTÄ PIDETTIIN \\ TÄRKEINÄ URAOHJAAJIEN
}

OSAAMISALUEINA.

ottaa asia puheeksi oikea-aikaisesti ja asiakasta tukevalla tavalla:

"Uraohjaajan työssä niillä [tunneälyllä ja tunteilla] on suuri merkitys, että semmonen tietynlainen herkkyys tulkita ja myös tavallaan ettii se oikea aika että sä pystyt ehottaan asioita ja ottaan puheeksi, ja sitten se että sä annat aikaa sille ihmiselle." (H1)

Kaikki haastateltavat kokivat, että etäohjauksen jatkuva lisääntyminen synnyttää väistämä̈ttä osaamistarpeita, jotka ovat sidoksissa vuorovaikutukseen ja asiakkaiden kohtaamisen erityispiirteisiin. Sosiaalisen median käyttö koettiin ajankohtaiseksi osaamistarpeeksi sekä asiakkaiden työnhaun että uraohjaajien verkostoitumisen ja ajankohtaisten keskusteluiden seuraamisen kannalta. Käytännön teknologiaosaamisen lisäksi uraohjaajat painottivat ymmärrystä digitalisaation vaikutuksista työelämään. Tekoäly, etätyömahdollisuudet ja työn sisältöjen muutokset vaativat heiltä kykyä ennakoida urien kehittymistä tulevaisuudessa.

Uraohjaajan työssä tarvitaan monipuolisia tiedonhankinnan ja soveltamisen taitoja. Haastateltavat kokivat erityisesti työ- ja elämänkokemuksen kehittäneen heidän kykyään soveltaa tietoa ja vastata moninaisen asiakaskunnan vaihteleviin tarpeisiin. He kokivat myös teoriatiedon lisäävän soveltamiskykyä; se tuo lisäymmärrystä, luotettavuutta ja työkaluja. Lait ja säädökset taas vaikuttavat suoraan asiakkaiden elämään, minkä vuoksi juridiikan tuntemusta pidettiin ensiarvoisen tärkeänä.

Ammatillisessa kehittymisessä haastateltavat pitivät erityisesti osaamispohjan jatkuvaa päivittämistä tärkeänä osaamisalueena:
"Työelämä muuttuu ja työnhaku muuttuu ja urat ei oo enää niin kauhean suoraviivaisia. Niin se haastaa sitten tällä kentällä toimivia itsessään, että pitää olla valmis mukautumaan ja kehittämään omaa osaamista koko ajan." (H6)

Asiakkaiden vaihtelevien tarpeiden ja taustojen sekä muuttuvien hakukäytäntöjen, ammattinimikkeiden ja säädösten vuoksi uraohjaajien on haastateltavien kokemusten mukaan jatkuvasti kehitettävä ajankohtaista osaamispohjaansa. Olennaista on lisäksi ennakointikyky, joka uraohjaajien puheessa näyttäytyy taitona ymmärtää tulevaisuuden työelämän muutoksia ja suhteuttaa kriittisesti tulevaisuusennusteita ja raportteja.

Globalisaation myötä kansainvälisyysosaamista pidettiin tärkeänä uraohjaajien osaamisalueena. Asiakkaiden enenevä suuntautuminen Suomen ulkopuolelle tai monikansallisiin yrityksiin luo uraohjaajille tarpeen ymmärtää kansainvälisiä työmarkkinoita. Maahanmuuton myötä heillä saattaa taas olla sekä asiakkaita että kollegoita muista kulttuuritaustoista. Uraohjaajien on siten sekä ymmärrettävä eri kulttuurien vaikutusta suomalaiseen työelämään että kyettävä kulttuurisensitiivisyyteen.

\section{Resilienssi ja metakognitiiviset kyvyt}

Haastateltavat toivat esiin kykyä joustaa, olla sinnikäs ja kestää työn henkistä vaativuutta, toisin sanoen resilienssien merkitystä ja vaadetta työssään. Niin ikään he sanoittivat metakognitiivista kyvykkyyttä eli taitoja jäsentää työssään niin suuria tietomäärï̈ kuin mutkikkaita asiakastilanteita, jotta ne selkiytyvät ja ovat hallittavia itselle sekä asiakkaille.

Verkostoissa toimimisen ja moniammatillisuuden merkitys on kasvanut, ja asiakkaiden haastavien tilanteiden myötä uraohjausprosessissa voi olla mukana sosiaalityöntekijä tai terapeutti. Uraohjaajat korostivat lisäksi työyhteisötaitoja ja kollegiaalisuutta: monimutkaisten tilanteiden ja oman työotteen yhteistä reflektointia pidettiin tärkeänä. Itsensä markkinoimisen taito korostui sekä kykynä myydä omaa osaamista ja uraohjauspalveluita että kykynä tukea asiakkaiden itsensä markkinoimisen taitoa. 


\begin{tabular}{|l|l|l|}
\hline Pääluokka & Yläluokka & Alaluokka \\
\hline Asiakasrajapinta & $\begin{array}{l}\text { Asiakastilanteiden haastavuus } \\
(\mathrm{N}=9)\end{array}$ & $\begin{array}{l}\text { a. Työkyvyn ongelmat } \\
\text { b. Ohjattavien tilanteiden monimutkaisuus } \\
\text { C. Asiakkaiden epärealistiset odotukset } \\
\text { d. Motivaation puute } \\
\text { e. Vuorovaikutuksen haasteet }\end{array}$ \\
\cline { 2 - 3 } & Etäohjauksen haasteet $(\mathrm{N}=6)$ & $\begin{array}{l}\text { a. Verkko-, video- ja puhelinohjauksen haasteet } \\
\text { b. Järjestelmien toimimattomuus }\end{array}$ \\
\hline $\begin{array}{l}\text { Uraohjaajien } \\
\text { toiminta }\end{array}$ & $\begin{array}{l}\text { Ammatillinen hajanaisuus } \\
(\mathrm{N}=9)\end{array}$ & $\begin{array}{l}\text { a. Yhtenäisyyden puute } \\
\text { b. Käsityserot ohjauksesta ja tuloksellisuudesta }\end{array}$ \\
\cline { 2 - 3 } & $\begin{array}{l}\text { Ohjaajan voimavarat }(\mathrm{N}=9) \\
\text { a. Ammatti-identiteetti }\end{array}$ \\
\hline $\begin{array}{l}\text { Yhteiskunnallinen } \\
\text { viitekehys }\end{array}$ & $\begin{array}{l}\text { Kansainvälisyyden haasteet }(\mathrm{N}=7) \\
\text { c. Ojana haksaminen } \\
\text { d. Ajanpuute }\end{array}$ \\
\cline { 2 - 3 } & $\begin{array}{l}\text { Yhteiskuntapoliittiset haasteet } \\
(\mathrm{N}=6)\end{array}$ & $\begin{array}{l}\text { a. Kansainvälisten työmarkkinoiden tuntemus } \\
\text { b. Kulttuuritietous } \\
\text { c. Kielen tuomat haasteet }\end{array}$ \\
\hline $\begin{array}{l}\text { a. Koulutus- ja työvoimapoliittiset päätökset } \\
\text { b. Tulkinnanvaraisuus } \\
\text { c. Järjestelmien jäykkyys }\end{array}$ \\
\hline
\end{tabular}

Taulukko 2. Luokittelu uraohjaajien kokemista työn haasteista.

Tietojenkäsittelyn taidot, eli tiedon jäsentäminen, suurten tietomäärien hallinta ja tiedonhaun taidot, koettiin olennaiseksi osaamiseksi. Uraohjaajat painottivat taitoa jäsentää asiakkaan kertomia asioita ja nostaa esille oikeanlaisia kysymyksiä ja päätelmiä. He pitivät tärkeänä kykyä hakea ja rajata tietoa sekä olla suurten tietomäärien "monitaituri ja akrobaatti".

Uraohjaajat kokivat työhyvinvointitaitoja koskevan osaamisen merkitykselliseksi. Esimerkiksi armollisuutta itseä kohtaan, eli omien virheiden ja inhimillisyyden myöntämistä, pidettiin tärkeänä. $\mathrm{He}$ korostivat lisäksi kykyä ottaa aikaa työstä palautumiseen työpäivänkin aikana ja sietää epävarmuutta niin asiakkaiden muuttuvien urien kuin oman työnsä suhteen. Eräs uraohjaaja pohti, että on vain pyrittävä luottavaiseen ajattelutapaan.

Haastateltavien mukaan eettisten taitojen ja ammattietiikan ulottuvuus näyttäytyi erityisesti tilanteissa, joissa uraohjaaja joutui kertomaan esimerkiksi ammattialan häviämisestä ja asiakkaan pärjäämättömyydestä. Uraohjaajat painottivat myös itsetuntemuksen merkitystä, sillä ohjaajan näkemykset työelämästä, yhteiskunnasta ja politiikasta vaikuttavat siihen, miten asiakas näkee työn roolin elämässään.

\section{URAOHJAAJIEN KOKEMAT TYÖN HAASTEET}

Uraohjaajien kokemat haasteet (taulukko 2) jakautuvat analyysimme perusteella kolmeen laajaan pääluokkaan. Ne ovat asiakasrajapinta, uraohjaajien toiminta sekä yhteiskunnallinen viitekehys.

\section{Asiakasrajapinta}

Asiakastilanteiden haastavuudesta puhuivat kaikki uraohjaajat erityisen paljon. Asiakkaiden työkyvyn ongelmien koettiin korostuvan, ja uraohjaajien oli aiempaa useammin ohjattava asiakkaat muun avun piiriin. Kasvavina haasteina korostuivat asiakkaiden mielenterveysongelmat ja puutteellinen ymmärrys työkyvystä. Eräs haastateltava kuvasi asiakkaiden työkyvyn haasteita seuraavasti:

"On näitä emotionaalisia esteitä ihmisillä ollu ennenkin, ja itse asiassa psykoterapeutit sanoo että se on lisääntynyt. Ja tämmönen niinkun, että on vaikeampi selviytyä näistä elämän vastoinkäymisistä, resilienssi on vähentynyt. Nämä taidot mitä ihmiset tarvii itsensä ohjaamiseen, tunnetaidot ja tämmöset on huonommassa jamassa ku aikaisemmin." (H4) 


\section{EP ̈̈SELV ̈̈T OHJEISTUKSET}

\section{JA HEIKKO TIEDOTUS}

\section{UUDISTUKSISTA JOHTIVAT}

TULKINNANVARAISUUTEEN.

Tarve ottaa huomioon asiakkaan elämänkenttä kokonaisuudessaan on haastateltavien mukaan monimutkaistanut uraohjaajien työtä samalla kun asiakkaiden tilanteet ovat monimutkaistuneet. Taustalla voi olla erilaisia elämäntilanteita, tarpeita, koulutuksia ja työkokemuksia. Vaikka tilanteet ovat monimutkaisia, monella asiakkaalla on epärealistiset odotukset, kuten että tavoitteet, osaaminen ja mahdollisuudet selviäisivät yhdellä käyntikerralla. Odotukset taas saattavat laskea motivaatiota, mikä näyttäytyi muun muassa haluttomuutena hakeutua täydennyskoulutuksiin sekä uraohjaustapaamisten keskeytymisenä.

Asiakasrajapinnassa haastateltavat kokivat merkityksellisimmiksi vuorovaikutuksen haasteiksi asiakkaiden luottamuksen ansaitsemisen, oman vuorovaikutustyylin sopeuttamisen asiakkaaseen ja kielteisten asioiden käsittelyn asiakkaiden kanssa. Luottamuksen myötä uraohjaukselle olennaiset asiat, kuten perheongelmat tai asiakkaan sitoutuminen terapiaan, voivat tulla esiin ajoissa ja aiemmin kuin luottamuksen puuttuessa. Asiakaskunnan moninaisuus loi uraohjaajille haasteita mukauttaa omaa vuorovaikutustyyliä asiakkaan tarpeisiin.

Etäohjauksen haasteet ilmenivät verkko-, video- ja puhelinohjauksessa ja järjestelmien toimimattomuutena. Vaikka joidenkin asiakkaiden voi olla helpompi käsitellä vaikeita asioita etänä, uraohjaajat kokivat erityisesti verkko- ja puhelinohjauksen haasteiksi sen, että esimerkiksi mielenterveyttä ja työkykyä koskevat seikat voivat jäädä uraohjaajalta pimentoon:

”Onhan meilläkin täällä testejä ja on testejä netissäkin ja verkossa, että on hirmu hyvä juttu, mutta sitten sieltä ei paljastu sen takaa sitten se ihmisen mielenterveys tai joku tämmönen persoonaproblematiikka mikä sitten paljastuu tässä. Usein pöydän toiselta puolelta näkee kaikenlaista." (H3)
Haasteena näyttäytyi haastateltavien mukaan lisäksi asiakkaiden haluttomuus etäohjaukseen, mikä voi osittain johtua järjestelmien toimimattomuudesta ja asiakkaiden suhtautumisesta verkon käyttöön. Haastateltavat pohtivat lisäksi palveluiden käytettävyysongelmia ja teknologian mukanaan tuomaa hakkeroinnin ja kaatuvien järjestelmien ongelmia.

\section{Uraohjaajien toiminta}

Haastateltavat kokivat, että kun uraohjaajat tulevat vaihtelevista taustoista, uraohjauksen kenttä ja ammattilaisuus pirstaloituvat, ja uraohjaajat kokevat yhtenäisyyden puutetta. Koska uraohjaus on suojaamaton nimike, monenlaista ohjausta aina pintapuolisesta neuvonnasta syvempään psykologiseen työhön voidaan kutsua uraohjaukseksi:

”Nykyään sitä uraohjausta käyttää vähän joka pulju. Että siellä on tosi laidasta laitaan mitä tällä nimellä käytetään, todella hyvää ohjausta ja sitten sellaista mitä aina ei myöntäis ohjaukseksi ollenkaan." (H8)

Asiakkaatkaan eivät aina tiedä, millaista ohjausta odottaa, eikä heidän tarpeisiinsa välttämättä pystytä vastaamaan. Yksi haastateltava ilmaisi huolensa siitä, että kentän hajanaisuus ja laadultaan vaihtelevat ohjaustavat saattavat heikentää uraohjauksen asemaa.

Asiakkaiden lisäksi uraohjaajilla on erilaisia käsityksiä uraohjauksesta ja sen tuloksellisuudesta. Jotkut haastateltavat eivät esimerkiksi pitäneet verkkoohjausta tai koulutusneuvontaa uraohjauksena vaan pikemminkin tiedon jakamisena. Eräs haastateltava taas huomautti, että ajattelutapa ja lähtökohdat voivat vaihdella julkisen ja yksityisen puolen välillä. Erityisenä tulevaisuuden haasteena uraohjaajat pitivät mahdollista työllisyyspalvelujen ja uraohjauksen rahoitusjärjestelmien muuttumista tulosperusteisteisiksi, jolloin osa alan yrityksistä sekä toimijoista saattavat valikoida asiakkaikseen vain niin sanotusti helposti työllistettäviä.

Haastateltavat käsittelivät puheessaan omien voimavarojensa riittävyyttä. Jotkut kertoivat oman ammatti-identiteettinsä kehittyneen hitaasti, ja epävarmuus omasta osaamisesta loi edelleen haasteen 
Mielenterveyden JA

TYÖKYVYN SEIKAT VOIVAT

J $\dddot{A}$ ÄDÄ ETÄOHJAUKSESSA

PIMENTOON.

sietää epävarmuutta sekä työelämän muutosten että oman työn osalta. Asiakkaiden kasvaneiden vaatimusten lisäksi jatkuva epävarmuus ja kiire luovat uraohjaajille jaksamisen haasteita. Heidän voi olla raskasta kohdata itse samanlaisia asioita, joita asiakkaat tuovat esiin:

"Mutta sitten kun oot itse mukana siinä samassa myllyssä mitä ne asiakkaat käy läpi, niin se on paljon raskaampaa. Ja sitten pitää olla taitoa siihen, että pystyy palautumaan ja pystyy kestämään sen epävarmuuden ja muutokset ja kaiken sen hulinan mitä elämään kuuluu." (H8)

Kasvaneet vaatimukset ja ennustamattomat muutokset lisäävät paineita pysyä ajan hermolla, joita yksi haastateltava vertasi kilpajuoksuksi muutosten kanssa. Uraohjaajien on pysyttävä ajan tasalla työelämässä, politiikassa ja koulutuksen kentällä ja kyettävä ymmärtämään, miten muutokset vaikuttavat asiakkaiden elämään. Kaikesta huolimatta uraohjaajien työtä haastaa ajanpuute, sillä itsensä kehittämiselle on järjestetty hyvin vähän työaikaa, ja ohjausajat voivat olla rajattuja.

\section{Yhteiskunnallinen viitekehys}

Globalisaation huomioiminen ja kulttuurisensitiivisyys korostuivat haastateltavien esiin nostamissa uraohjauksen osaamisalueissa (taulukko 1). Vastaavasti he kokivat kansainvälisten työmarkkinoiden tarpeiden, mahdollisuuksien ja käytäntöjen tuntemuksen haasteeksi työssään, kun asiakkaat suuntaavat kansainvälisille urille. Toisena seikkana haastateltavat puhuivat kieleen ja kielitaitoon liittyvistä haasteista työssään. Ne näyttäytyivät sekä ohjaajien että asiakkaiden osin puutteellisena kielitaitona tai vaikeutena sanoittaa asioita toisilleen erityisesti tilanteissa, joissa edes englannista ei löytynyt vastinetta työhistoriaan liittyvälle termille.

Yhteiskuntapoliittiset haasteet näkyivät puolestaan uraohjaajien kokemusten mukaan esimerkiksi poliittisissa päätöksissä, jotka loivat uraohjaukselle reunaehtoja. Haastatellut kokivat, että epäselvät ohjeistukset ja heikko tiedotus uudistuksista johtivat helposti tulkinnanvaraisuuteen: selvityksissä ja raporteissa voi olla ristiriitaista tai vain kapeasta näkökulmasta tuotettua tietoa, ja jopa lakeja saatetaan tulkita eri paikoissa eri tavoin. Uudistusten, lakien ja sääntöjen suhteen uraohjauksesta puuttuu siis yhtenäinen järjestelmä, minkä vuoksi tilanteita ei välttämättä arvioida oikealla tavalla. Lisäksi uraohjaajien työtä haastaa järjestelmien jäykkyys, mikä voi vaikeuttaa asiakkaan yksilöllisen ohjauspolun suunnittelua.

\section{POHDINTA}

Uraohjaajien kokemukset työssä tarvitusta osaamisesta kiteytyivät kahteen päluokkaan: 1) uraohjauksen tuntemus ja soveltaminen ja 2) uraohjaajien resilienssi ja metakognitiiviset kyvyt. Asiakkaan vahvistaminen sekä ohjaajan vuorovaikutus- ja tietotekniset taidot näyttäytyivät uraohjaajan tärkeimpinä osaamisalueina. Työssä koetut haasteet puolestaan jakautuivat kolmeen pääluokkaan: 1) asiakasrajapinta, 2) uraohjaajien toiminta ja 3) yhteiskunnallinen viitekehys. Korostuneimmat haasteet koskivat asiakastilanteiden haastavuutta, ammatillista hajanaisuutta ja ohjaajan omia voimavaroja.

Tulokset myötäilevät pitkälti aiempia, normatiivisia osaamisviitekehyksiä (ks. s. 211). Esimerkiksi ohjaustyön eettisyyden korostaminen, ohjaustaidot, kulttuurisensitiivisyys, itsetuntemus, uraohjauksen tuntemus ja soveltaminen, ammatillinen kehittyminen, verkostoituminen, teoriatieto ja teknologiaosaaminen vastasivat hyvin tuloksiamme. Sen sijaan uraohjaajien oman jaksamisen eli ammatillisen hyvinvoinnin teemat eivät ole yhtä vahvasti läsnä osaamisviitekehyksissä kuin haastateltaviemme puheessa. Erona osaamisviitekehyksiin korostui myös psykologinen osaaminen, erityisesti asiakkaan vahvistaminen, työkykyosaaminen ja mielenterveysosaaminen, joilla ei kuitenkaan tarkoiteta psykologista hoitotyötä. 


\section{URAOHJAAJIEN TYÖ VAATII YMM ̈̈RRYST $\ddot{A}$ TYÖKYVYST $\ddot{A}$} JA VOIMAANNUTTAMISESTA.

Oman ammatillisen hyvinvoinnin ja psykologisen osaamisen merkitys asiakastyössä on mahdollisesti korostunut aiempaa vahvemmin uraohjaajillakin vasta viime vuosikymmenenä, mikä voi johtua esimerkiksi työelämän tahdin kiristymisestä.

Tulosten pohjalta voidaan todeta, että aikamme tieto- ja palveluyhteiskunnan synnyttämien monitahoisten haasteiden myötä yksilöt tarvitsevat urataitoinaan mahdollisesti enemmän psyykkisiä taitoja ja vahvuutta kuin aiemmin. Vaikka uraohjaus ei ole terapiaa, se voi tulevaisuudessa ammentaa yhä enemmän niin positiivisen psykologian (Seligman \& Csikszentmihalyi 2000) kuin käyttäytymisterapian muodoista, kuten hyväksymis- ja omistautumisterapiasta (Pietikäinen 2017), jotka keskittyvät elämän merkityksellisyyteen sekä haasteista selviytymiseen yksilön vahvuuksia, voimavaroja ja psykologista joustavuutta kehittämällä.

Psykologisen osaamisen tarpeet ja haasteet tuottavat haasteita myös kasvavalle teknologian käytölle uraohjauspalveluissa. Vaikka etäohjaus on resurssien kannalta mielekästä ja sillä voidaan taata uraohjauspalveluiden saatavuus, tutkimuksemme tulosten mukaan työkyvyn ja mielenterveyden ongelmat eivät välttämättä tule esiin etäohjauksessa. Teknologian enenevä käyttö herättää lisäksi kysymyksen siitä, miten eri ikäryhmien suhde teknologiaan ja verkkolukutaito voidaan huomioida etäohjauksessa (vrt. Kuoppamäki 2018).

Jotta asiakkaille voidaan taata riittävä tuki kaikissa elämänvaiheissa, heidän vaihtelevat tarpeensa ja rajoitteensa on otettava huomioon uraohjauksessa. Sosiaalisen median ja teknologian tehokas käyttö työssä vaatiikin uraohjaajilta kykyä ymmärtää ja hallita verkkopohjaisia palveluita ja sovittaa dynaamisesti yhteen kognitiivisia, sosiaalisia, emotionaalisia ja eettisiä tekijöitä (Kettunen 2017).
Tutkimuksemme osoittaa, että uraohjaajien työ vaatii ymmärrystä työkyvystä ja voimaannuttamisesta, samalla kun heidän on rakennettava luottamusta ja otettava huomioon asiakkaan persoona, toiveet ja rajoitteet. Monipuolisten ohjaustaitojen ja teorioiden tuntemuksen lisäksi uraohjaajien on hallittava laajasti tietotaitoa työ- ja opiskelumahdollisuuksista ja muista asiakkaiden elämään kuuluvista asioista sekä samanaikaisesti kehitettävä itseään ja pidettävä huolta jaksamisestaan. Siten uraohjauksen rinnalla voidaan puhua holistisesta ura- ja elämänsuunnittelusta, jossa työ rakentaa merkityksellistä elämää (Hartung 2010; Savickas ym. 2009).

Tuloksiamme voidaan tarkastella myös ohjausalan koulutusten, kuten vuonna 2018 Suomessa käynnistyneiden uraohjauksen erikoistumiskoulutusten opetussuunnitelmien ja koulutussisältöjen, näkökulmista. Niissä näyttäytyvät muun muassa teoriatieto, verkostoituminen ja vuorovaikutusosaaminen, mutta esimerkiksi psykologinen osaaminen on heikosti läsnä (Uraohjauksen erikoistumiskoulutus 2019a, 2019b \& 2019c). Kestävän uran käsite korostaa samoin yksilön psykologisen toimintakyvyn ymmärryksen osaamistarvetta uraohjauksessa ja urien pohdinta kestävyyden näkökulmasta auttaa käsittelemään työelämän monimutkaistumista (Vos, de \& Heijden, van der 2015).

Uraohjauksen kannalta onkin olennaista, miten ohjaajat pystyvät tukemaan asiakkaiden merkityksellisiä, motivoivia ja kiinnostavia urapolkuja, jotka vastaavat heidän arvojaan ja ovat sovitettuja työn ulkopuoliseen elämään. Kestävän uran käsite ja prosessimalli tutkimuksessamme käsiteltyjen uraohjaajien kokemusten valossa tavoittavat jotain sellaista, mikä on osa uraohjaajien arkea.

Kun työelämä muuttuu ja yksilöllisten tarpeiden ja uravalintojen määrä kasvaa aikuiskoulutuksen ohella (Oksanen 2017), uraohjauksen tarpeellisuus ja merkitys korostuvat yhteiskunnassa. Uraohjaajien kyky tukea asiakkaiden kestävää ura- ja elämänsuunnittelua ja samalla vastata yhteiskunnan ja yksilöiden muuttuviin tarpeisiin on kriittinen kysymys nyt ja tulevaisuudessa. 


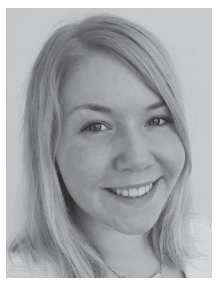

EMILIA LAMPI

$\mathrm{KM}$, yhteisömanageri

Peerage of Science

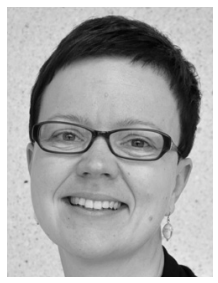

\section{KATJA VÄHÄSANTANEN}

KT, työelämän tutkimuksen

ja kehittämisen dosentti، yliopistotutkija

kasvatustieteiden laitos

Jyväskylän yliopisto

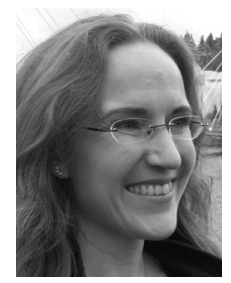

\section{JOHANNA RANTANEN}

PsT, työ- ja organisaatiopsykologian dosentti, yliopistotutkija psykologian laitos Jyväskylän yliopisto

\section{LÄHTEET}

Cedefop (European Centre for the Development of Vocational Training). (2009). Professionalizing Career Guidance - Practitioner Competences and Qualification Routes in Europe. Luxembourg: Office for Official Publications of the European Communities.

Coutinho, M., Dam, U. \& Blustein, D. (2008). The psychology of working and globalization: A new perspective for a new era. International Journal for Educational and Vocational Guidance 8(1), 5-18.

Douglas, F. (2010). Sustaining the self: Implications for the development of career practitioners' professional identity. Australian Career Development Journal 19(1), 24-32.

ELGPN (European Lifelong Guidance Policy Network). (2014). Lifelong Guidance Policy Development: Glossary. http://www.elgpn.eu/elgpndb/search/metadata/ view/185 (18.12.2018).

Elo, S. \& Kyngäs, H. (2008). The qualitative content analysis process. Journal of Advanced Nursing 62(1), 107-115.

Erikson, E. (1980). Identity and the Life Cycle. New York: Norton.

Harteis, C. (2018). Machines, change and work: An educational view on the digitalization of work. Teoksessa Harteis, C. (toim.) The Impact of Digitalization in the Workplace - An Educational View. Switzerland: Springer, 1-10.

Hartung, P. (2010). Practice and research in career counseling and development - 2009. The Career Development Quarterly 5 (2), 98-142.
IAEVG (International Association for Educational and Vocational Guidance). (2003). International Competencies for Educational and Vocational Guidance Practitioners. http://iaevg.net/iaevg.org/IAEVG/nav0f9a. html? lang=2\&menu=1\&sub-menu=5 (18.12.2018).

Julkunen, R. 2008. Uuden työn paradoksit - keskusteluja 2000-luvun työprosess(e)ista. Jyväskylä: Vastapaino.

Kauhanen, A. (2014). Tulevaisuuden työmarkkinat. Elinkeinoelämän tutkimuslaitos, ETLA raportit 30.

Kettunen, J. (2017). Career Practitioners' Conceptions of Social Media and Competency for Social Media in Career Services. Finnish Institute for Educational Research, Studies 32. Jyväskylä: University of Jyväskylä

Kubicek, B. \& Tement, S. (2016). Work intensification and the work-home interface: The moderating effect of individual work-home segmentation strategies and organizational segmentation supplies. Journal of Personnel Psychology 15(1), 76-89.

Kuoppamäki, S. (2018). The Role of Age and Life Course Stage in Digital Consumption. Department of Social Sciences and Philosophy, Studies 36. Jyväskylä: University of Jyväskylä.

LaPointe, K. (2014). Tilaa mielekkäälle työlle. Aikuiskasvatus 34(1), 17-28.

Lent, R. \& Brown, S. (2013). Career Development and Counseling: Putting Theory and Research to Work. Hoboken: Wiley.

Lindsay, P. \& Stuart, R. (1997). Reconstructing competence. Journal of European Industrial Training 21(9), 326-332. 
Meuser, M. \& Nagel, U. (2009). The expert interview and changes in knowledge production. Teoksessa Bogner, A., Littig, B. \& Menz, W. (toim.) Interviewing Experts. Research Methods Series. London: Palgrave Macmillan, 17-42.

Mulder, M. (2007). Competence - The essence and use of the concept in ICVT. European Journal of Vocational Training 40(1), 5-21.

NCDA (National Career Development Association). (2009). Minimum Competencies for Multicultural Career Counseling and Development. Oklahoma: NCDA.

NICE (Network for Innovation in Career Guidance \& Counselling in Europe). (2016). European Competence Standards for the Academic Training of Career Practitioners. http://www.nice-network.eu/download/ ecs-en-2016/?wpdmdl=973 (18.12.2018).

Niles, S. G., Yoon, H.-J., Balm, E. \& Amundson, N. (2010). Using a hope-centered model of career development in challenging times. Turkish Psychological Counseling and Guidance Journal 4(34), 101-108.

Oksanen, K. (2017). Valtioneuvoston tulevaisuusselonteon 1. osa: Jaettu ymmärrys työn murroksesta. Valtioneuvoston kanslian julkaisusarja 13a/2017.

Onnismaa, J. (2007). Ohjaus- ja neuvontatyö. Helsinki: Gaudeamus.

Patton, M. (2002). Qualitative Research and Evaluation Options. California: Sage.

Peavy, R. V. (1999). Sosiodynaaminen ohjaus. Konstruktivistinen näkökulma 21. vuosisadan ohjaustyöhön. Helsinki: Psykologien Kustannus Oy.

Pietikäinen, A. (2017). Joustava mieli tukena elämän kriiseissä. Helsinki: Duodecim.

Savickas, M. (2013). Career Counselling. Washington: American Psychological Association.

Savickas, M., Nota, L., Rossier, J., Dauwalder, J.-P., Duarte, M., Guichard, J., Soresi, S., Van Esbroeck, R. \& van Vianen, A. (2009). Life designing: A paradigm for career construction in the 21st century. Journal of Vocational Behavior 75(3), 239-250.

Seligman, M. \& Csikszentmihalyi, M. (2000). Positive psychology: An introduction. American Psychologist 55(1), 5-14.

Sultana, R. (2009). Competence and competence frameworks in career guidance: Complex and contested concepts. International Journal of Educational and Vocational Guidance 9(1), 15-30.
S\&Gs (The Canadian standards and guidelines for career development practitioners). (2012). https:// careercompetence.ca/canadian-standards-guidelinescareer-development-practitioners-sgs (18.12.2018).

Työ- ja elinkeinotoimisto. http://toimistot.te-palvelut. fi/ammatinvalinta-ja-urasuunnittelupalvelut (18.12.2018).

Työolotutkimus. (2013). Tilastokeskus - Työolotutkimus 2013. https://www.stat.fi/til/tyoolot/2013/tyoolot_2013_2014-11-26_fi.pdf (18.12.2018).

Uraohjauksen erikoistumiskoulutus. (2019a). https://uraohjauserko.fi (18.12.2018).

Uraohjauksen erikoistumiskoulutus. (2019b). https:// www.jamk.fi/fi/Koulutus/Taydennyskoulutus/ Opetus-ja-ohjaus/Ohjausosaaminen/uraohjauserko (18.12.2018).

Uraohjauksen erikoistumiskoulutus. (2019c). https:// www.jyu.fi/edupsy/fi/laitokset/okl/koulutusala/ohjausala/haku/uraohjaus (18.12.2018).

Vaismorandi, M., Turunen, H. \& Bondas, T. (2013). Content analysis and thematic analysis: implications for conducting a qualitative descriptive study. Nursing and Health Sciences 15(3), 398-405.

Vanhalakka-Ruoho, M. (2014). Toimijuus elämänkulussa - Ohjaustyön perusta? Aikuiskasvatus 34(3), 192-201.

Vehviläinen, S. (2014). Ohjaustyön opas - Yhteistyössä kohti toimijuutta. Helsinki: Gaudeamus.

Vos, de, A., Heijden, van der, B. \& Akkermans, J. (2018). Sustainable careers: Towards a conceptual model. Journal of Vocational Behavior. https://doi. org/10.1016/j.jvb.2018.06.011.

Vos, de, A. \& Heijden, van der, B. (2015). Handbook of Research on Sustainable Careers. Cheltenham: Edward Elgar.

Vuorinen, R. \& Kettunen, J. (2017). The European status for career service provider credentialing: professionalism in European Union (EU) guidance policies. Teoksessa Yoon, H.J., Hutchison, B., Maze, M., Pritchard, C. \& Reiss, A. (toim.) International Practices of Career Services, Credentialing and Training. Oklahoma: NCDA, 1-15.

Vähäsantanen, K. \& Eteläpelto, A. (2015). Professional agency, identity, and emotions while leaving one's work organization. Professions and Professionalism 5(3), 1-16. 